\title{
APPLICATION OF METADATA MODELING TO DISPUTE REVIEW REPORT MANAGEMENT
}

\author{
Yimin Zhu ${ }^{1}$, Mehmet Emre Bayraktar ${ }^{2}$, Shu-Ching Chen ${ }^{3}$ \\ ${ }^{1,2}$ Department of Construction Management, Florida International University, Miami, FL, USA \\ ${ }^{3}$ School of Computer and Information Sciences, Florida International University, Miami, FL, USA \\ E-mails: ${ }^{1}$ zhuy@fiu.edu; ${ }^{2}$ bayrakm@fiu.edu; ${ }^{3}$ chens@cs.fiu.edu \\ Received 4 May 2010; accepted 27 May 2010
}

\begin{abstract}
Disagreements in construction projects often result in litigation that is both time-consuming and expensive. A dispute review board (DRB) provides a valuable and proven alternative method of dispute resolution. Currently, the Florida Department of Transportation (FDOT) stores DRB reports in portable document format (PDF) with limited search capability. Improving information retrieval of DRB documents and providing a certain level of integration of DRB reports with relevant but heterogeneous data and documents is the key to enhancing the current FDOT DRB system. This paper presents a web-based data management framework to improve information management processes of the FDOT DRB system by providing key features such as metadata generation, an integrated review process, a simple issue description, member information management, and versatile information search. The new system not only allows DRB members and FDOT construction engineers to store and retrieve DRB reports but also provides more functionality to process those reports. New functionalities include a structured search based on the metadata of DRB reports, an unstructured search using advanced computer technology, and the integration of DRB reports with other related information for analysis. This type of functionality improves the efficiency and effectiveness of the DRB system.
\end{abstract}

Keywords: dispute resolution, contract documentation, information management, databases.

\section{Introduction}

Disputes refer to controversies or disagreements between different stakeholders. Often disputes may arise between owners and contractors during the execution of a construction project from different perceptions of the legitimacy and/or the quantum of claims (Kumaraswamy 1997; Pena-Mora et al. 2002). Construction disputes typically cause monetary and time losses. A dispute review board (DRB) provides a valuable and proven alternative method of dispute resolution. A DRB panel includes experienced industry professionals who are jointly selected by the owner and contractor of a project under contract. The panel reviews and recommends strategies for solving disputes that arise on a project (ASCE 1991; Matyas et al. 1996). The selection of board members is mainly based on the knowledge of claim issues and industrial experiences. According to a previous study, $89 \%$ of responders believed that the recommendations contained in DRB reports were equitable and well reasoned; $92 \%$ agreed that the results were logical and timely; and $98 \%$ considered the results useful in resolving the financial quarrel (Harmon 2003). The DRB method does not reduce the problems or recognize the deficiencies in documents. This method also does not mitigate potential claims on a project (Yates and Juan Duran 2006).

The Florida Department of Transportation (FDOT) began using DRBs in 1994. The practice was expanded to include the use of regional boards in 2002 and statewide boards in 2004. Currently, the FDOT makes DRBs available on every construction project. The FDOT maintains a website that stores all DRB decisions and recommendations (FDOT 2010). However, the current website listing of DRB decisions and recommendations does not provide illustrative information. The existing system is primarily a replicate of the paper-based DRB reports which is designed to manually store, classify, search, and organize the DRB reports. The website displays flat statements of the board decisions and the available reports have limited classification capability, e.g., search by district, subject, and results. Due to the lack of elaborative information, the DRB reports are not effectively used to guide construction engineers in resolving similar problems in other projects. If information from previous reports is required, the FDOT personnel searches for such information by going through the reports one by one.

The root cause of the problem is the data format of existing DRB reports. The reports are accessible as portable document format (PDF) documents, a format that is called unstructured data because it is not designed for computerized applications such as linking to different "sections" of standard specifications that are also in the PDF format. Consequently, using the system is very timeconsuming and it is error prone. Due to the fact that the reports are created and stored as PDF files, searching and grouping related DRB reports for further analysis is very difficult. As a result, users have trouble finding helpful 
information related to handling disputes or claims. As the number of FDOT construction projects using DRBs increases, the proliferation of DRB cases further decreases the efficiency and effectiveness of the existing online system.

Based on the above discussion, the underlying objective of this paper is to present a web-based data management framework developed to improve information management processes of the FDOT Dispute Review Board System. The new system developed by the research team and recently adopted by FDOT not only allows DRB members and construction engineers to store and retrieve DRB reports online, but also provides additional functionality such as advanced text-based search mechanisms, management of DRB member data, and integration of DRB reports with other related documents. The subsequent sections of the paper first provide background information on construction document and metadata modeling followed by a discussion of the design and development of the DRB system in detail.

\section{Construction Documents and Metadata Modeling}

There are many different types of documents associated with the management of a construction project (Zhu et al. 2001). DRB reports are one type of such documents. One barrier to processing construction documents is that almost all of these documents, including the DRB reports, are semi-structured or even unstructured. This format replicates their paper-based counterpart. For example, DRB reports can be regarded as semi-structured because they contain structured data such as the project number, the contract number, and the report creation date. DRB reports also include unstructured text such as issues. In many cases, some information contained in the unstructured text is critical for processing the DRB report. The retrieval of DRB reports based on a certain type of issues requires unstructured text. However, this information is hidden in unstructured document text and is hard for computers to retrieve or analyze. An improved method is required for modeling the documents and the unstructured content of the documents (Zhu and Issa 2003).

Markup languages such as Structured General Markup Language (SGML) and eXtensible Markup Language (XML) are used to add semantics to documents (e.g., Decker et al. 2000). Many applications were based on this strategy. For example, Zhu and Issa (2003) discussed the application of XML to structure construction documents, e.g., RFIs and change orders. They also discussed the use of tags that are defined by the markup language as a foundation for integrating data and information from other structured or unstructured sources.

The text content of those documents can be handled by using metadata. Metadata are defined as the data describing data (NISO 2004). They are used to describe unstructured text and to provide a mechanism for integrating the unstructured text with other relevant, yet heterogeneous data. In addition, metadata associated with the text of documents can help retrieve the text. The three types of metadata include descriptive, structural, and administrative (NISO 2004). Descriptive metadata mainly describe a resource and provide semantics for the identification and discovery of the resource. Structural metadata indicate the inherent structure of an object such as the document structure of a DRB report. Administrative metadata provide administrative support of an object such as the location of the object and the time when the object is created or accessed. Metadata can be created by human authors or by automatic machine generation (Duval 2001). NISO (2004) provides detailed information on the tools that can be used to create metadata. These tools include templates, mark-up tools, extraction tools, and conversion tools.

Many applications in the architecture engineering and construction (AEC) industry have used metadata for different purposes such as information retrieval and interoperability. Leung et al. (2003) proposed a metadatabased construction information system for data exchange among web-based documents. This system retrieved data from original documents, which was commonly called customized searching function. Then, the system reorganized the unstructured information according to specific tasks or users and displayed information in an integrated web page. Chan and Leung (2004) used metadata to develop a web-based document management system facilitating construction document management and information exchange. More recently, Mao et al. (2007) demonstrated the use of a metadata model for RFI documents to integrate heterogeneous data that includes the construction process and project management information. Integration of this data can facilitate construction document processing.

In addition to using metadata, text mining-based approaches that handle unstructured or semi-structured construction documents are useful for data integration. For example, Caldas et al. (2005) proposed an unstructured construction data management methodology named Text Information Integration Methodology (TIIM). This method enables document classification, ranking and retrieval, and data analysis.

\section{Implementation Environment}

The proposed DRB system was built using Microsoft ASP.NET (2.0 Framework) along with Microsoft VB.NET. All pages and code were developed using Microsoft Visual Studio 2008. All active server pages (ASP) use Microsoft VB.NET for their server-side code. JavaScript and the AJAX Control Toolkit was used in the implementation of several ASP pages as well. All database tables were created and managed using SQL Plus and SQL Developer. Similarly, Oracle Text was used to create and maintain the indices used for the text search.

The application was designed following a threetiered architecture. The first tier is the Interface Level and includes all the pages with which users interact. The second tier is the Logic Level. This tier contains all the code that processes the data that is retrieved from the Interface level. Several data structures were created to make the manipulation of this information easier. Most information that is processed at this level is passed into the third tier for storage in the database. The third tier is the Storage Level. It receives data from the Logic level 
and stores the necessary information in the database. Many functions were developed at this level to make the access and storage of information in the database simple.

\section{The DRB System}

The arrangement of different components in the DRB system was critical to the unhindered flow of data among different system modules. As shown in Fig. 1, the system has three components: i) maintenance module, ii) information input module, and iii) report search module.

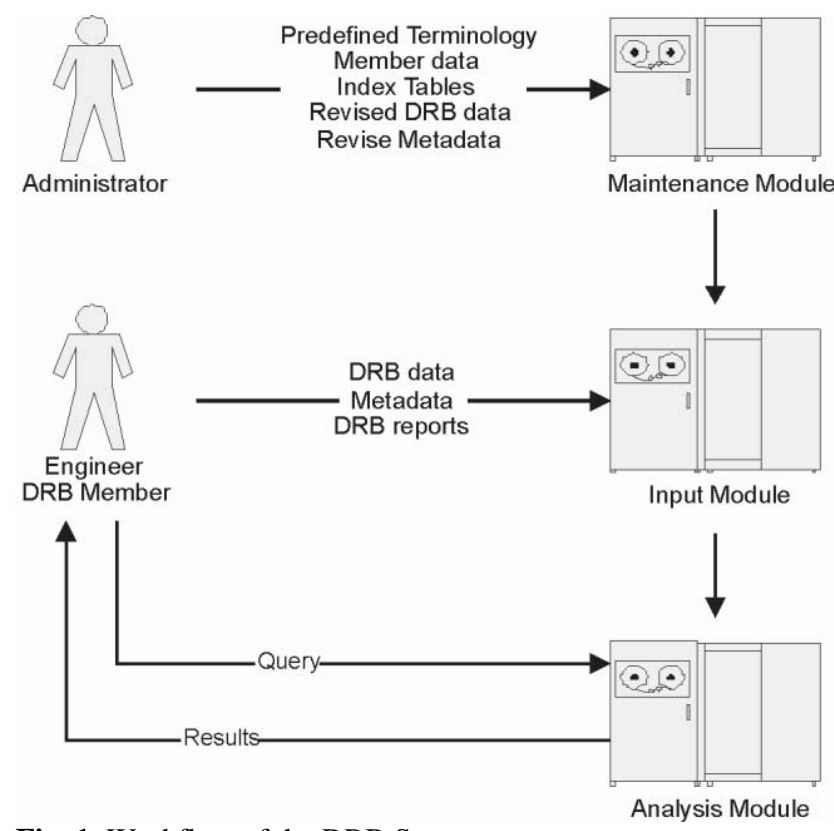

Fig. 1. Workflow of the DRB System

\subsection{Maintenance Module}

The maintenance module provides the following functions:

\section{Managing Access Rights}

Each user is assigned by the system administrator a username and a password for access control purpose. There are three types of access roles including administrator, engineer and DRB member. The specific access rights are defined in Table 1.

\section{Managing Member Data}

The maintenance module manages a list of DRB member data through three functions including creating a new member, updating a member, and deleting a member. Creating a new member adds the data of a new member to the member database and creates a user profile based on the assigned role of the member. Updating a member modifies information related to a particular member. Deleting a member deactivates a member so that the member cannot access the system. However, the member data are still stored. If a member becomes active again, his/her access rights are restored via the updating member procedure. The data associated with DRB members in- clude first name, middle initial (optional), last name, expertise, resume (optional), username, password, status (active or passive member), and access role. The above data are stored in a member database and used for member analysis. The access control data and the status data provide an administrative control method for better management of DRB members. The personal data (e.g., name, expertise and resume) provide some basic information about a member. Once a member is assigned to a DRB case, the database can track the history of a member's service on different dispute review boards over time.

Table 1. Access Rights of Different Roles

\begin{tabular}{|c|c|}
\hline Type & Access Rights \\
\hline Administrator & $\begin{array}{l}\text { - Has full access to all three modules of the } \\
\text { system; } \\
\text { - Can input reports and search through } \\
\text { reports; } \\
\text { - Can create, edit, and delete member ac- } \\
\text { counts; } \\
\text { - Can edit report metadata. }\end{array}$ \\
\hline Engineer & $\begin{array}{l}\text { - Has full access to the Input and Analysis } \\
\text { modules, but limited access to the } \\
\text { maintenance section; } \\
\text { - Can input reports, search reports, or edit } \\
\text { reports; } \\
\text { - Can edit DRB data using the maintenance } \\
\text { module; } \\
\text { - Does not have access to member mainte- } \\
\text { nance. }\end{array}$ \\
\hline DRB Member & $\begin{array}{l}\text { - Has full access to the Input and Analysis } \\
\text { module; } \\
\text { - Can input reports or search through the } \\
\text { reports; } \\
\text { - Has no access to the Maintenance section. }\end{array}$ \\
\hline
\end{tabular}

\section{Managing Index Tables}

The Construction Project Administration Manual (CPAM) and FDOT specifications are two examples of documents that are constantly referenced when processing or reviewing a DRB report. A citation to such external documents is often located in the position or recommendation section of a DRB report. There are two types of data associated with the development of links between a DRB report and the target documents, i.e., CPAM and the FDOT standard specifications. The first, DocumentType, specifies the document type; and the second, ReferenceLink, specifies the links to a particular section in the referenced document. There are five key processes in the integration of a DRB report with its target document. These processes include login, creating index table, saving index table, retrieving index table, and updating index table (Fig. 2).

The login process checks the authorization of a user for creating and accessing index tables based on the username and password. Most target documents have a structure, reflected by the level numbers and titles, or can be structured in this way. For example, the structure of the pre-construction division of the CPAM is shown in Fig. 3. 


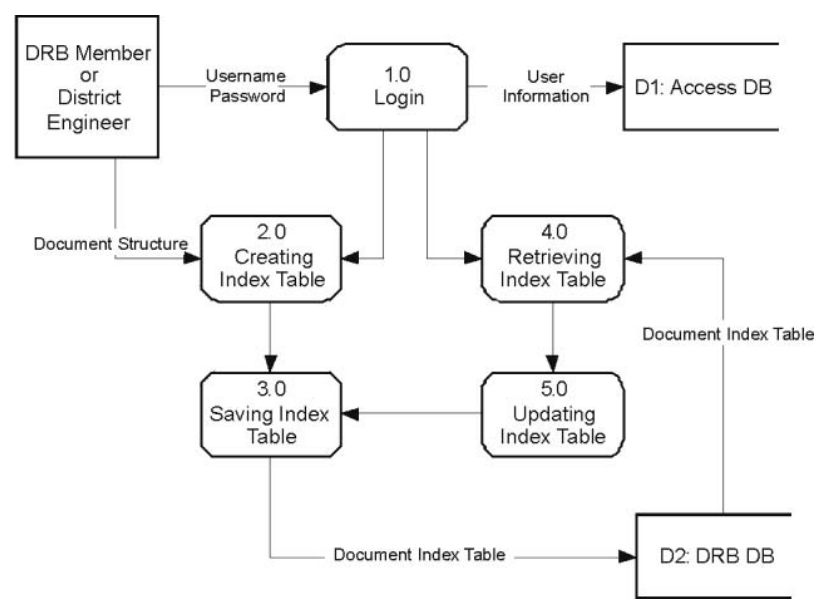

Fig. 2. Process Model for a Document Index Table

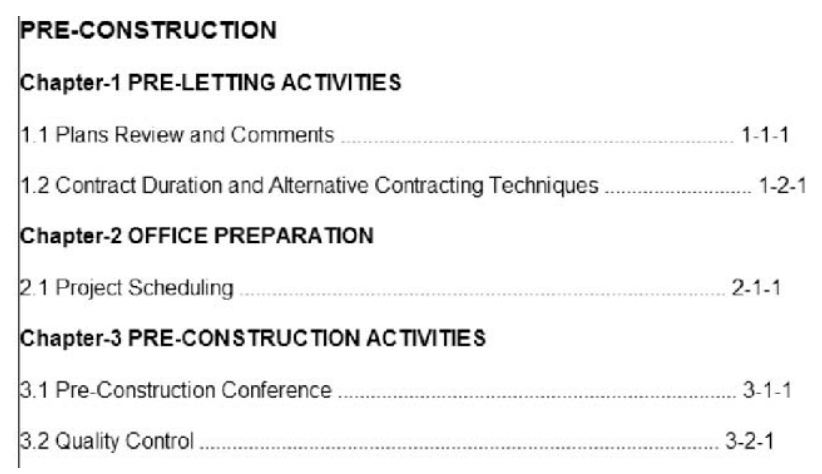

Fig. 3. Sample Document Structure

A tree structure, called an index table, is created in the maintenance module of the DRB system. This structure stores each level number and title so that they can be used to link a DRB report with the particular section of a target document. Due to limitations in the current implementation environment at FDOT, the creation of index tables is a manual process (i.e., server-side PDF processing is needed to improve this process). The system administrator or a designated FDOT engineer creates the index table manually and saves the index table in a database. If there is any change to the document structure, a new index table is created by updating the old one or generating a completely new table. In either case, the old index table is saved. In this way, previously established links are not broken.

As shown in Fig. 4, the data model of the index table contains two entities, IndexTable and IndexEntry. The IndexTable entity holds general information about an index table. It contains three types of data: DocumentType, Version, and Creation Date. DocumentType refers to the type of target document, such as CPAM or specifications. Version refers to the version of the index table for the same type of document. If there are changes to the CPAM, the system maintains a new version so that a DRB report may be linked to multiple versions of the CPAM. The Version data is used for this purpose. CreationDate records the date on which an index table is created. The IndexEntry entity contains specific information regarding each entry of the index table. It contains two types of data including LevelNumber and LevelTitle. LevelNumber records the level number of a title. For example, the level number for "Project Scheduling" in Fig. 3 is "2.1." LevelTitle refers to the title at a certain level, e.g., Project Scheduling. Each IndexTable may contain multiple IndexEntrys and each IndexEntry may have multiple sub-entries. Using this method, a hierarchical tree structure is modeled.

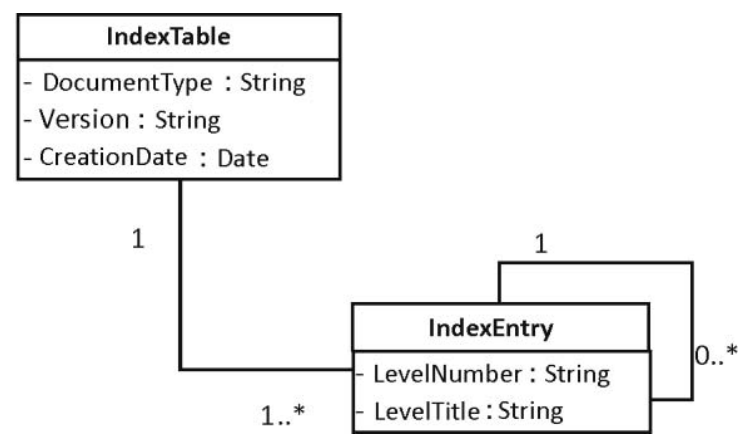

Fig. 4. Data Model of Index Tables

\section{Managing DRB Reports}

As discussed in the following section, the information input module provides a template for users to input DRB data and upload DRB reports to the database. Occasionally, the uploaded data may need adjustment such as correcting an error or better describing an issue. In those cases, this function provides a tool for the system administrator to update DRB data.

\section{Managing Preset Terminology}

Some terms in the DRB system which are preset and defined to provide clarity to users may need to be updated over time. This function allows the system administrator to manage those changes and maintain the consistency of the system.

\subsection{Information Input Module}

The information input module enables the user to upload DRB data and DRB reports to the database. In order to develop the information input module, the structure of seventy one DRB reports from FDOT District-1 was evaluated by performing a text analysis. Major types of data and section titles in these reports were identified and recorded in a spreadsheet. Based on the results of the analysis, the information input module was developed to include four components: i) basic information, ii) issue information, iii) position information, and iv) recommendation.

\section{Basic Information}

This component captures the basic information in a DRB report (Fig. 5). Major types of data include:

- Date when a DRB report is created;

- District that is involved in the dispute; 
- Participant information, e.g., contact information of the contractor or subcontractor;

- Report reference information, e.g., the FIN or the contractor number;

- Construction project reference;

- Subject of the DRB report;

- Involved DRB members.

DISPUTE REVIEW BOARD RECOMMENDATION HEARING NO. 6, Issue No. 1

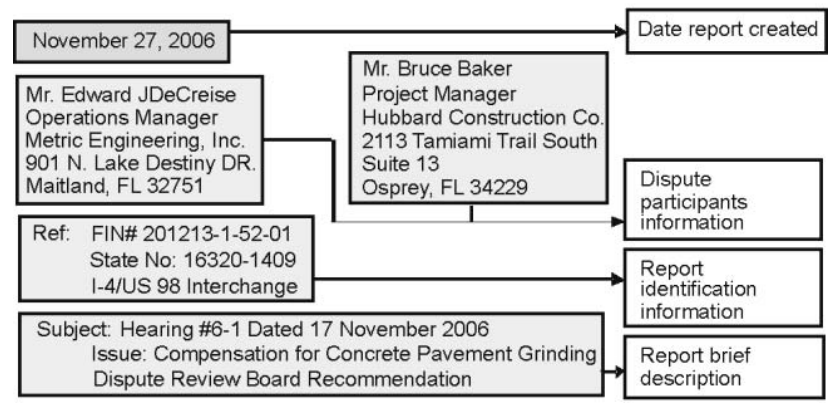

Fig. 5. Sample Basic Information of a DRB Report

\section{Issue Information}

Templates were created to capture dispute issue metadata. A dispute issue is a short paragraph that provides detailed information about a dispute. It includes the initiator of a claim, the request from the claimer, such as the requested compensation of time (days) or money (dollars) or both (Fig. 6). The paragraph describes the rationale of the claim by describing causes such as weather, materials, equipment, additional work, or different site conditions. For example, an issue can be stated as: "the contractor requests entitlement to additional contract time and recovery of costs for the water use permit delay". In this example, the initiator (the contractor), the request (additional time and cost), and the cause of the dispute (water use permit delay) are clearly spelled out. The developed DRB system captures four types of information for each issue including the claim type (e.g., excusable delay, compensable delay, breach of contract, and request of equitable adjustment), causation, related highway component, and issue description.

\section{Position Information}

The position refers to either the contractor or the FDOT position. The metadata of a position focuses on establishing connections between the position section and the external documents referenced by the position section. Thus, the metadata of the position section captures the type of referenced documents such as the FDOT standard specifications or CPAM, and the actual link to the referenced documents (Fig. 7).

\section{Recommendation Information}

Finally, the information input module enables a user to capture metadata that is related to DRB recommendations. These data include whether the ruling is in favor of the agency or the contractor, an explanation for the recommendation, acceptance of the recommendation by the agency (i.e., FDOT accepts, FDOT rejects, or partial acceptance), and relevant reference document numbers.

\subsection{Report Search Module}

The report search module provides two types of complementary mechanisms to support information search i.e., structured and unstructured. The structured information search is based on the DRB data model. It is composed of two types of searches. The first one, called the basic search, conducts searches that are associated with a set of pre-defined criteria related to a DRB report such as the contract number, district number, report creation date, claim type, and dispute causation. A user can construct a search from any combination of these data. For example, the user may search for DRB reports that are related to a certain district on a particular type of claim. A user can also use FIN numbers and contractor numbers to narrow a search. The second type of structured search, an advanced search, expands the basic search by allowing a user to set search criteria other than the basic facts of a report. Search criteria can include external documents referenced by the DRB reports or the results of a DRB recommendation (either in favor of contractor or the agency, etc.).

\section{ISSUE OVERVIEW}

Original Contract Plans included grinding of concrete pavement that was partially de-
leted and placed in adjacent contract. In addition the Plans Note that called for Grin-
ding "all new and existing concrete pavement" was also deleted. The Contractor and
the FDOT had differing opinions and how the remaining grinding payment was to be
paid. After several attempts to resolve the issue failed, the contractor filed notice of
intent to claim for payment for the change to plans and the payment item.

The DRB held a Hearing (28 April 2005) on the original Issue which was, "Should the Contractor be paid for grinding concrete pavement placed on the project. The Board rendered a unanimous opinion that, "Hubbard Construction is entitled to payment for grinding pavement as noted on the Plans Sheet 8 , Note \#6 that was present at the time of Bid". The Board did not recommend additional costs incurred by Hubbard for this grinding as stated in HCC's Position Paper.

Fig. 6. Sample Issue 


\section{Contractor Position - Hearing \# 6-1}

\section{The contractor's position is summarized as follows:}

"The board previously recommended for entitlement to the additional costs incurred by Hubbard for the concrete pavement grinding required to meet the straightedge requirements under Section 350 (corrective grinding) after hearing the issue on April 28, 2005. Hubbard and the Department have been unable to come to an agreement regarding the amount of compensation to which Hubbard is entitled. The engineer unilaterally elected to measure the areas where grinding was evident and provide compensation at the unit price included in the contract for profile grinding of the entire surface. Corrective grinding requires multiple mobilization and, unlike profile grinding of the entire surface, has an undetermined quantity. These cost elements inhibit the efficiency of the corrective grinding as compared to profile grinding, and as such is priced differently by grinding subcontractors. Hubbard's position is that the corrective grinding efforts are of a substantially different nature from the profile grinding on which the contract unit price was based. The compensation at the unit price as measured and determined by the engineer does not provide compensation for the actual costs incurred. Attempts by Hubbard to negotiate the issue have been unsuccessful.

Hubbard Construction was asked for entitlement for additional compensation in accordance with Section 4-3.2 (Extra Work) of the Contract documents.

FDOT Position - Hearing \#6-1

Specification requirement

The Department's position is stated in their conclusion of the position paper:

"As both the HCC's position statement and the Dispute Review Board's rational (from previous hearing) dictate that Note 6 , on Plan Sheet 8 , applied to all concrete pavements, existing and proposed at the time of bid, it can only be concluded that the unit price provided by HCC was for that of all concrete pavement grinding to be performed. It seems reasonable that both surface tolerance grinding and the profile grinding are included in Pay Item Number 2352-70, Grinding Concrete Pavement, as outlined in Note 6. In addition, as the increased quantities of the pay item do not meet the requirement of the Supplemental Specification 4-3 is a significant change a unit price adjustment is not warranted.

Contract provisions

Consequently, based on all the above, it is the Department's position that the Dispute Review Board should rule that there is no entitlement for HCC's request for a unit price adjustment or additional compensation and should uphold the Department's original denial of the request based on the facts and the language contained within the pertinent contract documents.

Fig. 7. Sample Positions of a DRB Report

On the other hand, the unstructured information search is designed based on the capability of existing text search engines. A user simply needs to input the keywords to conduct the search. In addition, a user can define a logical relationship between the keywords to refine the search results.

\section{Benefits of the new DRB System}

The benefits of the new DRB system are reflected by the following key features:

Simple data input yet useful results: with limited data input to capture information about a DRB report, the system provides FDOT engineers with capabilities to effectively and efficiently retrieve important information, review DRB cases, select DRB members with appropriate experience and expertise, and learn from lessons learned.

Integrated review processes: the system provides a capability to identify external documents that are associated with a DRB report. This makes DRB review processes, which typically use cited materials, much easier, compared to manually searching through specification sections or the construction project administration manual (CPAM) for specific information.
Simple issue description: having a consistent description of issues can help sort DRB reports in useful ways to support future decision-making. With the metadata of issues, this system provides a way to describe unstructured content and allow a user to directly search for a specific type of issue or sort issues according to their metadata. This is a very powerful feature, which can significantly improve handling DRB reports.

DRB member information management: DRB members play a significant role in handling disputes. Selecting appropriate members to a review board is very important. The system provides a mechanism to manage DRB member information in the context of dispute review activities. Such information can assist FDOT in many decisionmaking processes.

Versatile data analysis: the system provides two methods for data analysis. A user can use text search by entering keywords as search criteria to retrieve desired DRB documents. Or, the user can use a structured search by selecting one or several types of DRB data, such as FIN number, district, and member involved, to retrieve DRB reports. The versatility provides FDOT engineers many different ways to examine DRB reports.

The development of the new DRB system, the key features of which are described above, was based on a 
conventional software development process, which includes requirements elicitation, prototype development, evaluation, and refinement. Over the course of the research, a team of construction engineers and IT specialists from the Florida Department of Transportation closely worked with the design and development team at Florida International University. Thus, the efficiency and the effectiveness of the DRB system was ensured by constant interaction between the prospective user and the development team. The Florida DOT is currently in the process of replacing the existing system with the new one described in this paper. To put the benefits of the new DRB system into perspective, Table 2 provides a comparison of the existing and new DRB systems with respect to the three aspects deemed important by FDOT including: i) search capabilities, ii) integration with relevant data, and iii) integration with DRB member database.

Table 2. Comparison of the existing and new DRB Systems

\begin{tabular}{|c|c|}
\hline $\begin{array}{l}\text { Text-Based } \\
\text { Search }\end{array}$ & $\begin{array}{l}\text { New System } \\
\text { - Keyword based search through all reports } \\
\text { at a time. } \\
\text { - Search results can be classified based on } \\
\text { selected keywords. } \\
\text { Existing System } \\
\text { - Limited to one DRB report at a time. }\end{array}$ \\
\hline $\begin{array}{l}\text { Structured } \\
\text { Search }\end{array}$ & $\begin{array}{l}\text { New System } \\
\text { - Search based on pre-defined commonly } \\
\text { searched data such as project identifier, } \\
\text { claim characteristics, positions of parties, } \\
\text { and DRB decisions. } \\
\text { Existing System } \\
\text { - Not available. }\end{array}$ \\
\hline $\begin{array}{l}\text { Integration } \\
\text { with relevant } \\
\text { Data }\end{array}$ & $\begin{array}{l}\text { New System } \\
\text { - A link to the particular section in CPAM } \\
\text { or the specifications is established when } \\
\text { that section is cited in the DRB report. } \\
\text { Existing System } \\
\text { - Not available. }\end{array}$ \\
\hline $\begin{array}{l}\text { Integration } \\
\text { with Member } \\
\text { Database }\end{array}$ & $\begin{array}{l}\text { New System } \\
\text { - Search for DRB members who are in- } \\
\text { volved in a particular DRB. } \\
\text { - Search for DRB members with particular } \\
\text { background and expertise. } \\
\text { Existing System } \\
\text { - Not available. }\end{array}$ \\
\hline
\end{tabular}

\section{Conclusions}

This paper presented a web-based data management framework that uses Oracle-based Web technologies to improve information management processes of the FDOT Dispute Review Board System by providing key features such as metadata generation, an integrated review process, a simple issue description, member information management, and versatile information search. The new system not only allows DRB members and FDOT construction engineers to store and retrieve DRB reports, but also provides more functionality to process those reports. New functionalities include a structured search based on the metadata of DRB reports, an unstructured search us- ing advanced computer technology, and the integration of DRB reports with other related information for analysis. This type of functionality improves the efficiency and effectiveness of the DRB system.

The design and development of the new DRB system is based on a set of core principles including user friendliness, an integrated environment, and extensibility. The user friendliness addresses not only the issues associated with data and information display or presentation, but also the search or information retrieval capability of the system. Through metadata models, the proposed system can be integrated with external files and database systems. This capability can also be extended as more user requirements are identified in the future. These core principles can be applied to other projects that deal with unstructured data similar to DRB reports. In construction, many construction documents such as change orders and request for information are examples of unstructured or semi-structured documents. The capability of information systems to retrieve relevant information is critical for the effectiveness of such systems. The core principles applied to the system presented in this paper can potentially be helpful to the design of other construction information management systems.

\section{Acknowledgements}

The authors would like to thank the Florida Department of Transportation for sponsoring this research.

\section{References}

ASCE, American Society of Civil Engineers. 1991. Avoiding and resolving disputes during construction: Successful practices and guidelines. Technical Committee on Contracting Practices of the Underground Technology Council, ed., Technical Committee, The American Society of Civil Engineers, New York.

Caldas, C. H.; Soibelman, L.; Gasser, L. 2005. Methodology for the Integration of Project Documents in Model-based Information Systems, Journal of Computing in Civil Engineering 19(1): 25-33. doi:10.1061/(ASCE)0887-3801(2005)19:1(25)

Chan, S. L.; Leung, N. N. 2004. Prototype Web-Based Construction Project Management System, Journal of Construction Engineering and Management 130(6): 935-943. doi:10.1061/(ASCE)0733-9364(2004)130:6(935)

Decker, S.; Melnik, S.; Van Harmelen, F.; Fensel, D.; Klein, M.; Broekstra, J.; Erdmann, M.; Horrocks, I. 2000. The Semantic Web: The roles of XML and RDF, IEEE Internet Computing 4(5): 63-73. doi:10.1109/4236.877487

Duval, E. 2001. Metadata Standard: What, Who \& Why, Journal of Universal Computer Science 7(7): 591-601.

Florida DOT Dispute Review Board [cited 10 April 2010]. Available from Internet: <http://www.dot.state.fl.us/ construction/CONSTADM/DRB/DRBMain.shtm>.

Harmon, M. J. 2003. Effectiveness of Dispute Review Board, Journal of Construction Engineering and Management 129(6): 674-679. doi:10.1061/(ASCE)0733-9364(2003)129:6(674)

Kumaraswamy, M. 1997. Conflicts, Claims and Disputes in Construction, Engineering, Construction and Architectural Management 4(2): 95-111. doi:10.1108/eb021042 
Leung, N.; Chan, S. L.; Issa, R. R. A. 2003. Meta-Data-Based Collaboration in Construction Project Management, in Proccedings of The 4th Joint International Symposium on Information Technology in Civil Engineering, Nashville, TN USA, November 15-16, 2003, 1-12.

Mao, W.; Zhu, Y.; Ahmad, I. 2007. Applying Metadata Models to Unstructured Content of Construction Documents: a View-Based Approach, Automation in Construction 16(2): 242-252. doi:10.1016/j.autcon.2006.05.005

Matyas, R. M.; Mathews, A. A.; Smith, R. J.; Sperry, P. E. 1996. Construction Dispute Review Board Manual. McGraw-Hill, New York, NY.

National Information Standard Organization (NISO). 2004. Understanding Metadata. July 26, 2004.

Pena-Mora, F.; Sosa, C.; McCone, S. 2002. Dispute Avoidance and Resolution in Large Scale Civil Engineering Systems. MIT/Prentice Hall Civil and Environmental Engineering Textbook Series, August 2002.
Yates, J. K; Juan Duran, P. E. 2006. Utilizing Dispute Review Boards in Relational Contracting: A Case Study, Journal of Construction Engineering and Management 132(4): 334-341.

Zhu, Y.; Issa, R. R. A.; Cox, R. F. 2001. Web-Based Construction Document Processing via a 'Malleable Frame, Journal of Computing in Civil Engineering 15(3): 157-169. doi:10.1061/(ASCE)0887-3801(2001)15:3(157)

Zhu, Y.; Issa, R. 2003. Viewer Controllable Visualization for Construction Document Processing, Automation in Construction 12(3): 255-269. doi:10.1016/S0926-5805(02)00089-4

\section{METADUOMENŲ TAIKYMAS GINČŲ APŽVALGOS ATASKAITŲ VALDYMUI MODELIUOTI}

\section{Y. Zhu, M. E. Bayraktar, S.-C. Chen}

\section{S antrauka}

Dèl nesutarimų vykdant statybos projektus dažnai kyla teisminių ginčų, kurie yra brangūs ir trunka ilgai. Vertingas ir praktikoje prigijęs alternatyvus ginčų sprendimo metodas yra ginčų nagrinejjimo taryba (GNT). Šiuo metu Floridos transporto departamentas (FTD) yra sukaupęs GNT ataskaitas PDF formatu su ribota paieškos galimybe. GNT dokumentų informacijos paieška ir tinkamo lygio GNT ataskaitu integravimas su reikalingais, bet heterogeniniais duomenimis yra esminè prielaida tobulinti dabartinę FTD GNT sistemą. Straipsnyje pristatoma internetinè duomenų valdymo sistema, skirta patobulinti FTD GNT valdymo procesą remiantis šiomis esminėmis savybėmis: metaduomenu generavimo, integruoto peržiūros proceso, paprasto ginčo aprašymo, dalyvio informacijos valdymo, visapusiškos informacijos paieškos. Naujoji sistema ne tik leidžia FTD BNT nariams saugoti bei rasti GNT ataskaitas, bet ir sudaro galimybes funkcionaliau jas apdoroti. Naujos sistemos funkcijos apima struktūrizuotą paiešką GNT ataskaitų metaduomenų pagrindu, restruktūrizuotą paiešką naudojant pažangias kompiuterių technologijas ir GNT ataskaitų integravimą su kita susijusia analizuojama informacija. Šios funkcinès savybès pagerina GNT sistemos efektyvumą.

Reikšminiai žodžiai: ginčų sprendimas, sutarčių dokumentai, informacijos valdymas, duomenų bazès.

Yimin ZHU. Assistant Professor of Construction Management in the College of Engineering and Computing at Florida International University, USA. His major research focus is on the application of information technology to construction engineering and management. He has worked in the software industry as a software developer and an XML architect. Dr. Zhu has been studying systems integration for many years and published several articles on this subject. Dr. Zhu has served as the principal investigator for several Florida DOT research projects.

Mehmet Emre BAYRAKTAR. Assistant Professor of Construction Management in the College of Engineering and Computing at Florida International University, USA. His research interests include development of innovative computer based risk assessment and strategic management decision support systems and solutions for transportation infrastructure planning, management, and finance. Dr. Bayraktar has specific research experience in decision making systems for evacuation under hurricane emergency, social and economic impacts of disasters, PPPs in transportation, warranty contracting, and cost-schedule optimization in highway projects.

Shu-Ching CHEN. Professor of School of Computing and Information Sciences in the College of Engineering and Computing at Florida International University, USA. His main research interests include distributed multimedia database management systems and multimedia data mining. He also has extensive research experience in LiDAR data processing. Dr. Chen has been the PI/Co-PI of many research grants from NSF, National Oceanic and Atmospheric Administration (NOAA), Department of Homeland Security, Naval Research Laboratory (NRL), and Florida Office of Insurance Regulation (OIR). 